\title{
Peripheral Osteoma of Mandibular Angulus: Analysis of the Literature and Report of a New Case
}

\section{Osteoma periférico del ángulo mandibular: Análisis de la literatura e informe de un nuevo caso}

Hasan Ozturk DDS'; Damla Torul DDS1; Ezgi Yuceer DDS¹; Rifat Karli MD²; Sancar Baris MD³

1. Department of Oral and Maxillofacial Surgery, Faculty of Dentistry, Ondokuz Mayis University, Samsun, Turkey.

2. Department of Otolaryngology, Faculty of Medicine, Ondokuz Mayis University, Samsun, Turkey.

3. Department of Pathology, Faculty of Medicine, Ondokuz Mayis University, Samsun, Turkey.

Correspondence to: Dr. Ezgi Yuceer - ezgiyuceer@hotmail.com

Received: 20-XI-2017

Accepted: 13-II-2018

Published Online First: 22-II-2018

DOI: https://doi.org/10.15517/ijds.v0i0.32521

\section{ABSTRACT}

Osteoma is a benign osteogenic neoplasm originating from the continuous proliferation of compact and/or cancellous mature bone. The tumor can be classified as peripheral, central or extra-skeletal regarding location and it commonly seen in the cranio-facial region especially at the skull and paranasal sinuses. The exact etiology of the tumor is still controversial; however, it is considered that infection, trauma, muscle activity contributes the occurrence of the tumor. Due to the slow growing nature of osteoma, it is coincidentally detected on radiographs or when the tumor reaches a large size enough to trigger symptoms and cause facial disfigurement. Although mainly detected in the craniofacial bones, osteomas are rarely located in the jaw bones. The purpose of this review, is to present the diagnosis and treatment plan of a peripheral osteoma in the mandibular angulus region of an 8-year-old boy together with a review of published cases of peripheral osteomas of mandibular angulus.

\section{KEYWORDS}

Odontogenic tumor; Mandible; Osteoma; Angulus; Treatment. 


\section{RESUMEN}

El osteoma es una neoplasia osteogénica benigna que se origina de la proliferación continua de hueso maduro compacto y/o esponjoso. El tumor se puede clasificar como periférico, central o extraesquelético con respecto a la ubicación y se ve comúnmente en la región craneofacial, especialmente en el cráneo y los senos paranasales. La etiología exacta del tumor sigue siendo controvertida; sin embargo, se considera que la infección, el trauma y la actividad muscular contribuyen a la aparición del tumor. Debido a la naturaleza de crecimiento lento del osteoma, se detecta casualmente en las radiografías 0 cuando el tumor alcanza un tamaño grande lo suficiente como para desencadenar síntomas y causar desfiguración facial. Aunque se detecta principalmente en los huesos craneofaciales, los osteomas rara vez se localizan en los huesos de la mandíbula. El objetivo de esta revisión es presentar el diagnóstico y el plan de tratamiento de un osteoma periférico en la región angular mandibular de un niño de 8 años junto con una revisión de casos publicados de osteomas periféricos de angulación mandibular.

\section{PALABRAS CLAVE}

Tumor odontogénico; Mandíbula; Osteoma; Ángulo; Tratamiento.

\section{INTRODUCTION}

Osteoma is a benign, slow growing tumor composed of mature compact or/and cancellous bone $(1,2)$. It can be classified as central, peripheral, or extra-skeletal regarding the location and origin of the tumor. Central osteoma originates from the endosteum, while peripheral and extraskeletal types originate from periosteum and soft tissue, respectively $(1,3,4)$. Osteomas are rarely detected in the jawbones. The most common type of jaw osteoma is peripheral osteoma (PO) which is more often involves mandible than maxilla (5). Different hypotheses have been suggested about the etiology including congenital anomalies, inflammation, muscular activity, embryogenic changes, trauma, viral and endocrinal pathologies $(6,7)$. However, the exact origin of this pathology is still under debate. Varbonceur et al. (8) considered that this pathology has a developmental origin and arise from the embryological cartilaginous rests, persistent embryological periosteum cells or the suture between bones. According to researchers favoring the reactive theory, reactive response as a result of inflammation, trauma, and muscle traction contribute the development of this pathology. Kaplan et al. (9) postulated that sub- periosteal bleeding or edema associated with trauma cause periosteal elevation and subsequent muscle traction triggers the reactive response of the bone. They claim that this mechanism explains why osteomas are more likely to arise in areas which the strong muscle attachments are present and susceptible to trauma $(9,10)$. On the other hand, because of the limited but continuous growth potential of the osteomas that can reach huge sizes, they are also considered as neoplastic lesions $(1,7,11)$.

The osteoma is reported to occur at any age but young adults are more commonly affected by the tumor with no gender differences (1-3). Clinically, osteomas are usually asymptomatic and detected on routine radiographic examinations. They have slow and continuous growing potential that can cause facial asymmetry or disfigurement without any complaints $(9,11)$. Radiographic appearance of the osteoma is characterized by an oval, radiopaque, well-circumscribed mass approximately $1-4 \mathrm{~cm}$ in diameter, with a density similar to that of normal bone. The presence of an oval, radiopaque well circumscribed mass attached by a broad base or pedicle to the affected cortical bone is the hallmark of peripheral osteoma $(3,11)$. 
The purpose of this article is to present a case of peripheral osteoma causing facial asymmetry in the mandibular angulus of an 8-years-old boy and review the published cases about non-syndromic, peripheral osteomas of mandibular angulus in the literature. To achieve this goal a search of the literature was carried out on PubMedMEDLINE and the google scholar databases, till 2017. Search was performed using the keywords 'osteoma', 'solitary', 'peripheral', 'mandible', words and combination of these. Only the case reports with available full text were included.

\section{CASE REPORT}

An 8-years-old boy reported to the Department of Oral and Maxillofacial Surgery, Ondokuz Mayis University with a chief complaint of hard swelling in the left posterior region of the mandible. The patient was physically healthy and any systemic condition was not detected during anamnesis. The swelling was not associated with any pain, discharge, fever, paresthesia, or difficulty in mastication. The patient did not recall or confirm any history of trauma or infection in that region. On clinical examination, a solitary, non-pulsatile and approximately $1.5 \mathrm{~cm}$ in diameter, bony mass was palpated at the left angle region of the mandible. The tumor found fixed to the underlying bone and the skin overlying the tumor was in a healthy appearance. The panoramic radiography and cone beam computed tomography (CBCT) scan showed a well circumscribed, radiopaque mushroom like image located on the left angle of the mandible (Figures 1,2). The 3D reconstruction of the computed tomography image revealed a pedunculated homogeneous bony mass attached to the left angle of the mandible (Figure 3). The lesion was completely excised using an extra oral approach under general anesthesia (Figure 4). The surgical specimen was submitted for histopathological examination. Histopathological examination revealed a sclerotic lamellar bone nodule with almost no intertrabecular space (Figure 5). These features confirmed the final histopathologic diagnosis to be peripheral osteoma. The post-operative course was uneventful with a satisfactory healing (Figure 6). The patient is still under follow-up.

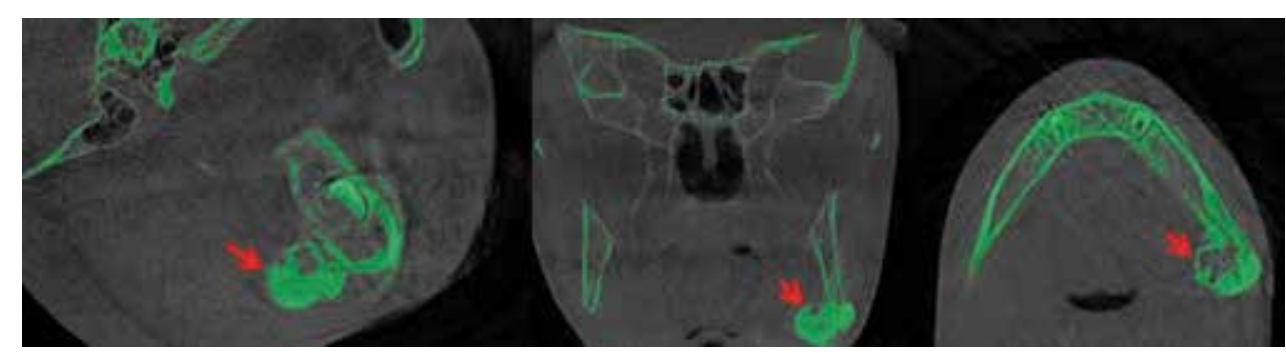

Figure 1. The pre-op CBCT showing radiopaque lesion on sagittal, coronal and axial plans.

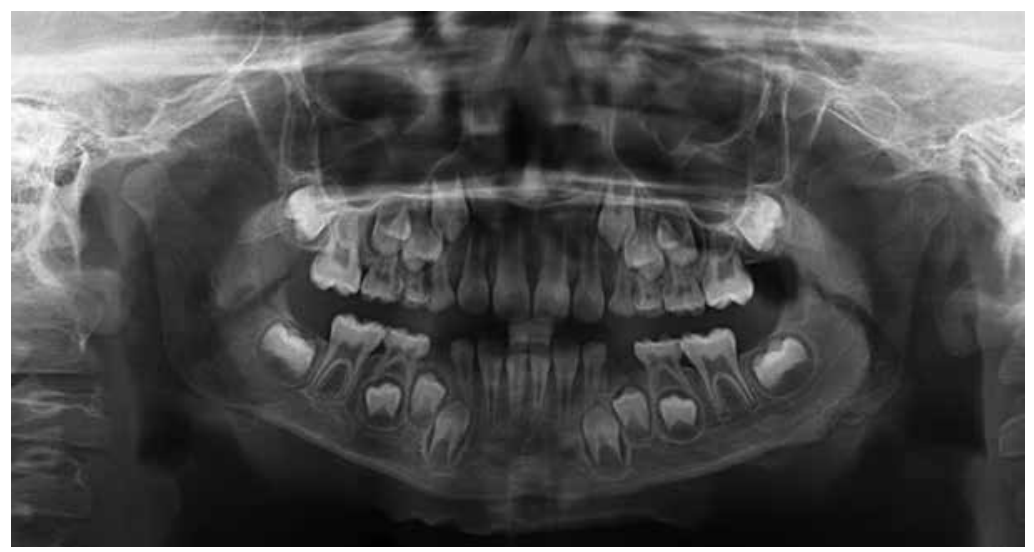

Figure 2. The pre-op panoramic view. 

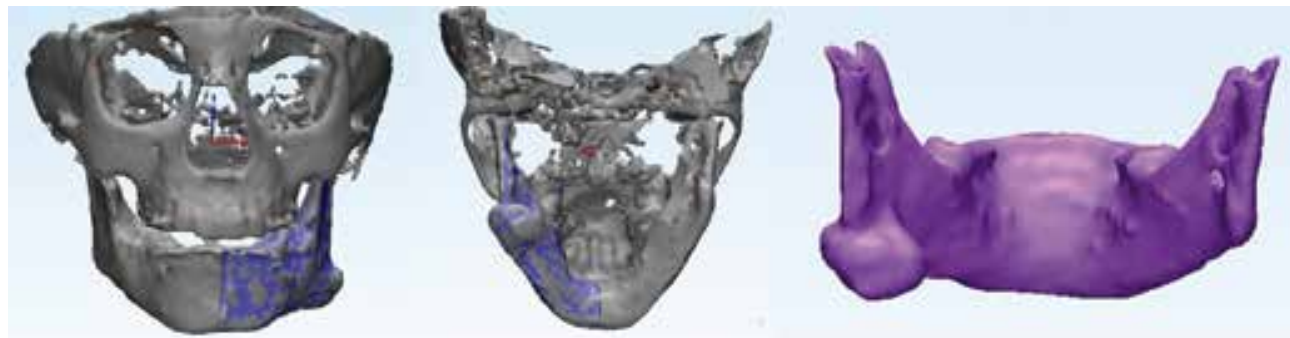

Figure 3. The 3D reconstruction of the osteoma attached on the left mandibular angle.

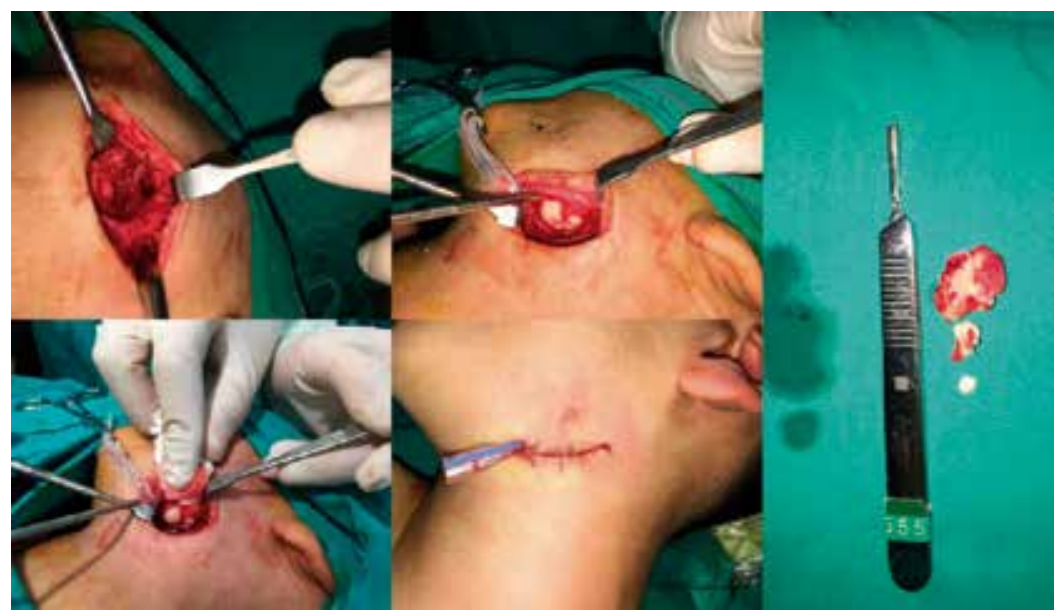

Figura 4. Intra operative photographs showing the excision of the osteoma and the specimen.

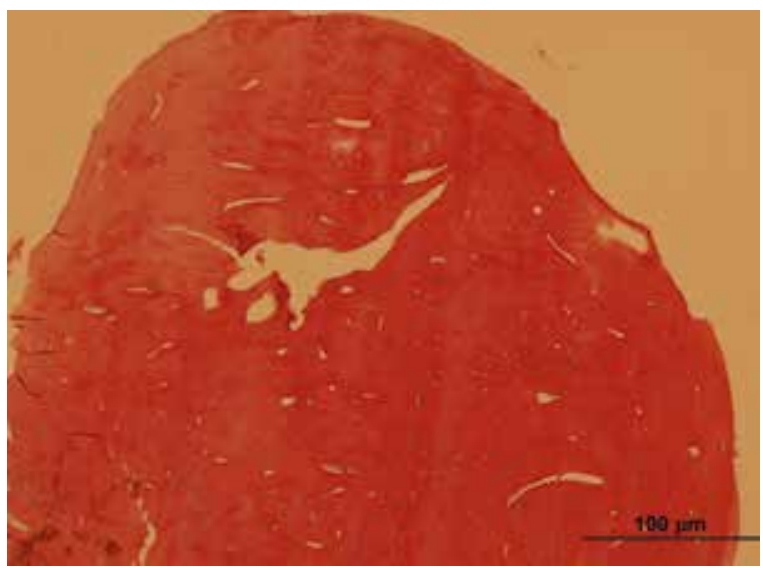

Figure 5. Low power microphotograph showing sclerotic lamellar bone nodule with almost no intertrabecular space. Hematoxylin \& eosin $\times 25$. 


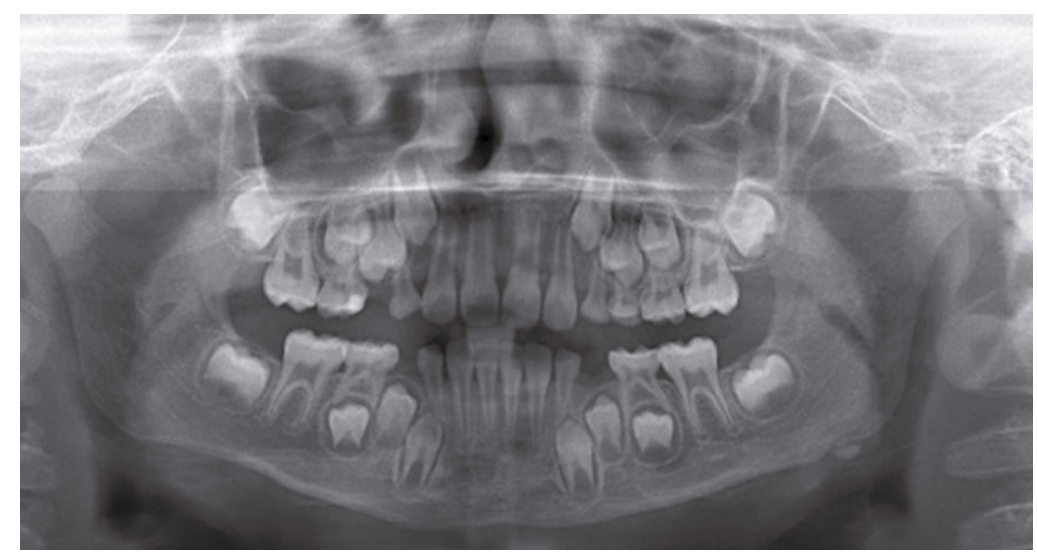

Figure 6. The post-op panoramic view (6 months after surgery).

\section{DISCUSSION}

Osteoma is a rare pathologic entity which was first described by Jaffe in 1935 (5). The real prevalence of this pathology is unknown. It estimated that the frequency of the osteoma is low, affecting 0.01-0.04\% of the population (12). In the latest WHO classification osteoma is defined as a true neoplasia of well differentiated mature bone tissue rather than a hamartoma (1). However, the exact origin of this pathology is still under debate. Among the published cases of peripheral osteoma of mandibular angle and in our case, trauma or any other etiologic factor cannot be determined (13-19).

Osteomas can be classified as peripheral, central or extra-skeletal. Solitary peripheral or so called periosteal type originates from the periosteum, as in our patient (20). Solitary POs can occur at any age but are commonly observed in young adults without any gender predilection (1-3). Similarly, published cases of the peripheral osteomas located in the mandibular angulus were detected mostly in the patients at 2nd and 3 rd decades of their lives (Table 1). Our case is the youngest among the other published cases of osteomas in the mandibular angle. Thus, management of the present case with the least invasive approach is more critical than the other cases, in terms of not to negatively affect the growth pattern of the patient's jaw.

Osteomas show continuous and a slowly growing pattern if left untreated (9). The most common locations of POs are the paranasal sinuses including frontal, ethmoidal and maxillary sinuses. Among the craniofacial sites POs are rarely seen in the jaws but when occur in the jawbones it mostly affect the mandible (5). In the study of Sayan et al. (21) which consist 35 cases of $\mathrm{PO}$, it is reported that majority of the POs $(22.9 \%)$ were detected in the mandible. The common locations reported in the mandible are the posterior lingual aspect of the body, angle and inferior border of the mandible $(2,5)$. In the review of the literature conducted by Ragupathy et al. (12) in 2013, out of 87 P0s $41.3 \%$ of cases were located in the body of the mandible, $21.83 \%$ in the condyle, $16.09 \%$ in the angle, $11 \%$ in the ascending ramus, $8 \%$ in the coronoid process and $2.2 \%$ in the sigmoid notch. In our case PO was located in the mandibular angle which is one of the most common places reported in the literature.

Osteomas usually stay silent and are often incidentally detected on a routine radiographic examination or when the tumor reach a large 
size enough to trigger symptoms and cause facial disfigurement (11). Generally, painless facial asymmetry is the reason of the patient to apply to the dentist. In most of the published cases of peripheral osteoma located in the mandibular angulus the main complaint of the patient is painless swelling $(10,13,5,17,22-24)$. Difficulty in mastication, swallowing, and breathing secondary to large osteomas has also been reported $(2,25$, 26). In the case report of Sadeghi et al. (27) a giant PO $(9.5 \times 8 \mathrm{~cm})$ caused dyspnea. Similar to the majority of published cases in the literature, any symptoms accompanying to the facial asymmetry were not detected in our case.

Usage of the most effective imaging modality pose a crucial role in the conservative management of the osteomas. Different imaging modalities like occlusal and panoramic radiographs, Waters view, computerized tomography (CT), magnetic resonance imaging (MRI), or CBCT can be used for the radiographic examination of POs (28). It is reported that $P O$ s in the craniofacial region are best visualized and localized by means of CT $(29,30)$. In most of the cases in the literature the radiographic examination of the osteoma was performed with CT (14-16,31-33). However, because of it requires less radiation doses and provides higher quality of images than CT scan, we preferred CBCT in the radiographic examination of our case. Also, different from the majority of other published cases of osteoma in the mandibular angle, we used 3D modelling in our case to perform the treatment more precisely. As far as we aware, there was only one published case which use CBCT scan and $3 \mathrm{D}$ modelling together for the management of the angle osteoma (13).

The differential diagnosis of osteomas include exostoses, osteochondroma, osteoid osteoma, periosteal osteoblastoma, parosteal osteosarcoma, peripheral ossifying fibroma, Paget's disease, fibrous dysplasia, and odontoma. Careful evaluation of the clinical behaviors, radiographic and histologic features of the lesions are required to reach correct diagnosis (28). Treatment of asymptomatic osteomas is controversial. Recommended general approach allows a conservative attitude toward asymptomatic lesions (5). Durao et al. (19) prefered to keep the lesion under observation because of the small size and asymptomatic behavior of the lesion in their case. Surgical intervention is indicated only if it becomes large enough to cause facial asymmetry and functional impairment (1-3). In the case of mandibular POs, an intraoral approach is preferable for cosmetic reasons. But for the POs that are located in the posterior region of the mandible, extra-oral approach is preferred (14). Ochiai et al. (31) reported a minimal invasive procedure with endoscopy assisted piezo surgery that drastically reduce the risk of complication and damage to the adjacent vital structures. In our case, the patient was reported with a lesion at the angle of the mandible. Hence an extra-oral approach was preferred to adequately reach the lesion just like to the other published cases of angular osteomas $(13-15,34,35)$. 
Table 1. Peripheral osteomas of mandibular angle in the literature.

\begin{tabular}{|c|c|c|c|c|c|c|c|c|}
\hline Author/Year & Age/Sex & Side & Complaint & Size (cm) & Approach & $\begin{array}{c}\text { History of } \\
\text { trauma or } \\
\text { infection }\end{array}$ & Duration & Complication \\
\hline Present case 2017 & $8-\mathrm{M}$ & $\mathrm{L}$ & FA & $1.5 * 1.5$ & GA, EOA & No & NA & None \\
\hline Bhaskar et al. 2016(13) & $31-M$ & $\mathrm{~L}$ & PS & $3 * 3$ & $L A, E O A$ & No & $6 \mathrm{MO}$ & None \\
\hline Gopanabonia et al. 2016 (15) & $26-\mathrm{F}$ & $\mathrm{L}$ & PS & $1.5^{\star} 1.5$ & GA, EOA & No & $1 Y$ & None \\
\hline Kshirsagar et al. 2015 (14) & $27-\mathrm{F}$ & $\mathrm{R}$ & - & $1.5^{\star} 1.5$ & GA, EOA & No & $2 Y$ & None \\
\hline $\begin{array}{l}\text { Shetty and Biddappa } \\
2015 \text { (16) }\end{array}$ & $16-\mathrm{F}$ & $\mathrm{L}$ & PFS & $2 * 2$ & $\begin{array}{l}\text { GA,EOA } \\
(I G, R P)\end{array}$ & NA & $1 Y$ & None \\
\hline Orabona et al. 2015 (22) & $25-\mathrm{M}$ & $\mathrm{R}$ & PS & 2.3 & $N A, I O A$ & NA & NA & Dysesthesia \\
\hline Orabona et al. 2015 (22) & $29-\mathrm{F}$ & L & $P$ & 1.1 & NA & NA & NA & None \\
\hline Orabona et al. 2015 (22) & $28-\mathrm{F}$ & $\mathrm{L}$ & PS & 3.8 & NA & NA & NA & None \\
\hline De Souza et al. 2014 (23) & $41-\mathrm{F}$ & L & PS & 2 & $\csc$ & NA & NA & None \\
\hline Soni and Bhargava 2014 (36) & $60-\mathrm{M}$ & $\mathrm{R}$ & PFS & $5 * 3$ & $\mathrm{NA}, \mathrm{SR}, \mathrm{RP}$ & No & $1 Y$ & None \\
\hline Kumar et al. 2014 (34) & $42-\mathrm{M}$ & $\mathrm{R}$ & FA & $3 * 3$ & GA, EOA & No & $3 Y$ & None \\
\hline Figuerido et al. 2014 (17) & $20-\mathrm{M}$ & $\mathrm{R}$ & PS & NA & $N A, 10 A$ & No & $2 Y$ & NA \\
\hline Ochiai et al. 2013 (31) & $33-\mathrm{M}$ & $\mathrm{R}$ & PFS & $2 * 2.5$ & $\mathrm{GA}, \mathrm{END}-\mathrm{PZ}$ & No & NA & None \\
\hline Herford et al. 2013 (33) & $46-\mathrm{F}$ & $\mathrm{R}$ & FA & NA & $N A, I 0 A$ & NA & NA & None \\
\hline Han et al. 2013 (32) & $68-\mathrm{F}$ & $\mathrm{L}$ & FA & $4 * 3$ & $\mathrm{GA}, 10 \mathrm{~A}$ & NA & NA & None \\
\hline $\begin{array}{l}\text { Tarsitano and Marchetti } \\
2013(35)\end{array}$ & $41-\mathrm{M}$ & $\mathrm{R}$ & SN,D,FA & NA & GA, EOA & NA & $14 \mathrm{Y}$ & None \\
\hline De Franca et al. 2012 (37) & $33-\mathrm{F}$ & & PS & 2.5 & GA, NA & NA & $5 Y$ & None \\
\hline $\begin{array}{c}\text { Chattopadhyay and Chander } \\
2012 \text { (26) }\end{array}$ & $39-\mathrm{M}$ & L & FA,P,RMO & 3 & NA & NA & NA & NA \\
\hline $\begin{array}{c}\text { Chattopadhyay and Chander } \\
2012 \text { (26) }\end{array}$ & $56-\mathrm{M}$ & $L$ & $\mathrm{FA}, \mathrm{ST}, \mathrm{RMO}$ & 4 & NA & NA & NA & NA \\
\hline Horikawa et al. 2012 (18) & $N A-F$ & NA & - & NA & NA & NA & NA & NA \\
\hline Horikawa et al. 2012 (18) & $N A-F$ & NA & - & NA & NA & NA & NA & NA \\
\hline Durao et al. 2012 (19) & $57-\mathrm{M}$ & $\mathrm{L}$ & - & $1.6^{*} 1.2$ & KUO & No & NA & - \\
\hline Sheikh et al. 2011 (24) & $42-\mathrm{M}$ & $\mathrm{L}$ & PS & $3^{\star} 2$ & $L A, E O A$ & No & $8 Y$ & NA \\
\hline Mittal and lyer 2008 (38) & $35-\mathrm{M}$ & $\mathrm{L}$ & PS,FA & $4 * 4 * 4.1$ & GA, EOA & NA & $5 Y$ & NA \\
\hline Woldenberg et al. 2005 (29) & $40-\mathrm{M}$ & NA & FA & 2 & NA & NA & NA & NA \\
\hline Kerckhaert et al. 2005 (25) & $53-\mathrm{F}$ & $\mathrm{R}$ & DS & NA & GA, EOA & NA & $43 Y$ & None \\
\hline Kaplan et al. 1994 (9) & $31-\mathrm{M}$ & NA & NA & 1.5 & NA & No & $10 Y$ & NA \\
\hline Kaplan et al. 1994 (9) & $21-\mathrm{M}$ & NA & NA & 1 & NA & No & NA & NA \\
\hline Kaplan et al. 1994 (9) & 27-M & NA & NA & 1.5 & NA & No & $1.5 Y$ & NA \\
\hline Cutili et al. 1992 (10) & $22-\mathrm{F}$ & $\mathrm{L}$ & PS & 4 & GA, EOA & $\begin{array}{c}\text { Yes } \\
\text { (7Y Earlier) }\end{array}$ & NA & None \\
\hline
\end{tabular}

M: Male, F: Female, L: Left, R: Right PS: Painless swelling, PFS: Painful swelling, FA: Facial Asymmetry, SN: Snoring, D: Dysphagia, P: Pain, RMO: Reduction in mouth opening, ST: Sensitivity, DS: Difficulty in swallowing, LA: Local anesthesia, GA: General anesthesia, EOA: Ekstra-oral approach, IOA: Intra-oral approach, SR: Segmental Resection PZ: Piezo surgery, IG: lliac graft, RP: Reconstruction plate, CSC: Cross-sectional cervicotomy, END: Endoscopy, KUO: Keep under observation, MO: Month, Y: Year NA: Not available. 


\section{CONCLUSION}

Peripheral osteomas of the jaw bones are rare and usually detected incidentally because of the asymptomatic nature of the tumor. However, osteomas can become symptomatic and cause facial disfigurement along with the esthetic problems, in some cases. The use of appropriate imaging modality poses a crucial role in terms of the differential diagnosis of the tumor as it has a characteristic radiographical appearance. Local excision of the osteoma with the most conservative approach is critical to prevent post-operative esthetic and functional impairments.

\section{REFERENCES}

1. Agrawal R., Agrawal S., Bhargava S., Motlani M., Agrawal R. An Uncommon Case of Solitary Peripheral Osteoma in the Mandible. Case Rep Dent. 2015; 2015: 319738.

2. Gawande P., Deshmukh V., Garde J. B. A giant osteoma of the mandible. J Maxillofac Oral Surg. 2015; 14 (2): 460-465.

3. Bulut E., Acikgoz A., Ozan B., Gunhan O. Large peripheral osteoma of the mandible: a case report. Int J Dent. 2010; 2010: 834761.

4. Johann A. C., de Freitas J. B., de Aguiar M. C., de Araujo N. S., Mesquita R. A. Peripheral osteoma of the mandible: case report and review of the literature. J Craniomaxillofac Surg. 2005; 33 (4): 276-281.

5. Khandelwal P., Dhupar V., Akkara F. Unusually Large Peripheral Osteoma of the Mandible - A Rare Case Report. J Clin Diagn Res. 2016; 10 (11): 11-12.

6. Guimaraes K. B., Cavalcante J. R., FerraroBezerra M., Silva D.N., de Holanda Vasconcellos R. J., do Egito Vasconcelos B.C.
Peripheral osteoma bilateral of the mandible without association with Gardner syndrome. J Craniofac Surg. 2012; 23 (2): 83-86.

7. Mehta R., Yadav A., Bansal S. P., Deshpande M. D. Solitary Periosteal Osteoma of the Mandible: A case report. Sultan Qaboos Univ Med J. 2014; 14 (1): 145-148.

8. Varboncoeur A. P., Vanbelois H. J., Bowen L. L. Osteoma of the maxillary sinus. J Oral Maxillofac Surg. 1990; 48 (8): 882-883.

9. Kaplan I., Calderon S., Buchner A. Peripheral osteoma of the mandible: a study of 10 new cases and analysis of the literature. Journal of Oral and Maxillofacial Surgery. 1994; 52 (5): 467-470.

10. Cutilli B. J., Quinn P. D. Traumatically induced peripheral osteoma. Report of a case. Oral Surg Oral Med Oral Pathol. 1992; 73 (6): 667-669.

11. Kaya G. Ş., Omezli M. M., Sipal S., Ertas Ü. Gigantic peripheral osteoma of the mandible: a case report. J Clin Exp Dent. 2010; 2 (3): $160-162$.

12. Ragupathy K., Priyadharsini I., Sanjay P., Yuvaraj V., Balaji T.S. Peripheral Osteoma of the Body of Mandible: A Case Report. J Maxillofac Oral Surg. 2015; 14 (4): 1004-1008.

13. Bhaskar Y. H., Shaminey S. A., Gopika Manoharan G.M. Osteoma-A report of two cases. Int J Med and Dent Sci. 2016; 5 (1): 1083-1087.

14. Kshirsagar K., Bhate K., Pawar V., Santhosh Kumar S.N., Kheur S., Dusane S. Solitary Peripheral Osteoma of the Angle of the Mandible. Case Rep Dent. 2015; 2015:430619. 15. Gopanaboina S., Kumar P., Yadav Y., Rao M. Peripheral osteoma of the angle of mandible. Indian Journal of Dental Advancements. 2016; 8 (4): 259-263. 
16. Shetty S. K., Biddappa L. Recurrence of a giant peripheral osteoma of mandible. J Maxillofac Oral Surg. 2015; 14 (Suppl 1): 452-456.

17. Figueiredo N.R., Meena M., Dinkar A.D., Malik S. Peripheral osteoma of the angle of mandible. International Journal of Oral Health Sciences. 2014; 4 (1): 33-36.

18. Horikawa F. K., Freitas R. R., Maciel F. A., Goncalves A. J. Peripheral osteoma of the maxillofacial region: a study of 10 cases. Braz J Otorhinolaryngol. 2012; 78 (5): 38-43.

19. Durão A. R., Chilvarquer I., Hayek J. E., Provenzano M., Kendall M.R. Osteoma of the zygomatic arch and mandible: report of two cases. Revista Portuguesa de Estomatologia, Medicina Dentária e Cirurgia Maxilofacial. 2012; 53 (2): 103-107.

20. Ata-Ali J., Ata-Ali F. Giant peripheral osteoma of the mandible simulating a parotid gland tumor. Braz J Otorhinolaryngol. 2016; 1: 2.

21. Sayan N. B., Ucok C., Karasu H.A., Gunhan O. Peripheral osteoma of the oral and maxillofacial region: a study of 35 new cases. J Oral Maxillofac Surg. 2002; 60 (11): 1299-1301.

22. Dell'Aversana Orabona G., Salzano G., Iaconetta G., Piombino P., Ponzo L., Santella A., Astarita F., Solari D., Salzano F. A., Califano L. Facial osteomas: fourteen cases and a review of literature. Eur Rev Med Pharmacol Sci. 2015; 19 (10): 1796-1802.

23. Souza P. D., Leonhardt F. D., Ahumada N. G., Abrahao M., Cervantes O. Giant osteoma of the mandible. Braz J Otorhinolaryngol. 2015; 81 (1): 107-8.

24. Sheikh S., Pallagatti S., Aggarwal A., Singh R., Bansal N., Goyal G. Peripheral Osteoma of the mandible-a case report. Journal of Oral Health Research. 2011; 2 (4): 101-5.

25. Kerckhaert A., Wolvius E., van der Wal K., Oosterhuis J.W. A giant osteoma of the mandible: case report. J Craniomaxillofac Surg. 2005; 33 (4): 282-5.
26. Chattopadhyay C.P., Chander M. G. Peripheral osteoma of the maxillofacial region diagnosis and management: a study of 6 cases. J Maxillofac Oral Surg. 2012; 11 (4): 425-429.

27. Sadeghi H. M., Shamloo N., Taghavi N., Safi Y., Aghdashi F., Ismaeilnejad M. Giant Osteoma of Mandible Causing Dyspnea: A Rare Case Presentation and Review of the Literature. J Maxillofac Oral Surg. 2015; 14 (3): 836-40.

28. Kucukkurt S., Ozle M., Baris E. Peripheral osteoma in an unusual location on the mandible. BMJ Case Rep. 2016; 2016: 216554.

29. Woldenberg Y., Nash M., Bodner L. Peripheral osteoma of the maxillofacial region. Diagnosis and management: a study of 14 cases. Med Oral Patol Oral Cir Bucal. 2005; 10 (2): 139-42.

30. Rao S., Rao S., Pramod D.S. Transoral removal of peripheral osteoma at sigmoid notch of the mandible. J Maxillofac Oral Surg. 2015; 14 ( 1): 255-257.

31. Ochiai S., Kuroyanagi N., Sakuma H., Sakuma H., Miyachi H., Shimozato K. Endoscopicassisted resection of peripheral osteoma using piezosurgery. Oral Surg Oral Med Oral Pathol Oral Radiol. 2013; 115 (1): 16-20.

32. Han S. H., Kwon H., Jung S. N. Peripheral osteoma on the buccal aspect of mandible angle: a review of radiopaque masses and differential diagnosis. J Craniofac Surg. 2013; 24 (5): 1842-1844.

33. Herford A. S., Stoffella E., Tandon R. Osteomas involving the facial skeleton: a report of 2 cases and review of the literature. Oral Surg Oral Med Oral Pathol Oral Radiol. 2013; 115 (2): 1-6.

34. Surej Kumar L. K., Sudheena R., Varun Menon P. A rare form of peripheral osteoma: Case report. IJBRITISH. 2014; 1 (3): 76-79.

35. TarsitanoA., MarchettiC. Unusual presentation of obstructive sleep apnoea syndrome due to 
a giant mandible osteoma: case report and literature review. Acta Otorhinolaryngol Ital. 2013; 33 (1): 63-66.

36. Soni S., Bhargava A. Revisiting peripheral osteoma of the mandible with case series and review of literature. Indian J Otolaryngol Head Neck Surg. 2014; 66 (2): 212-218.
37. de Franca T. R., Gueiros L. A., de Castro J. F., Catunda I., Leao J. C., da Cruz Perez D. E. Solitary peripheral osteomas of the jaws. Imaging Sci Dent. 2012; 42 (2): 99-103.

38. Mittal A., Iyer N. Large peripheral osteoma of the mandible. Oral Radiology. 2008; 24 (1): 39-41. 